\title{
International Activities of U.S. Banks and in U.S. Banking Markets
}

James V. Houpt, of the Board's Division of Banking Supervision and Regulation, prepared this article. Mark Peirce, as well as Steve Schacht and Suzie Taylor, provided assistance with data.

The globalization of financial markets, made possible largely through market deregulation and technological gains, has been widely recognized. Increased trading and derivatives activities, in particular, are often cited as making financial markets more liquid and efficient and bringing markets throughout the world closer together. International lending by U.S. and foreign banks, along with international trade and the innovative financing necessary to support trade and economic growth, has also grown rapidly in recent decades.

Nevertheless, the extent of global markets and economies can be exaggerated, and trends can be reversed. Lenders and investors constantly reassess risks, and government actions affect the openness and attractiveness of markets to outsiders. The record of international banking, and of international trade in general, is not one of uninterrupted growth, as wars, social and political forces, and shifting economic and financial conditions of countries change markets and business patterns.

A review of data on the activities of U.S. banks abroad and foreign banks in the United States can reveal much about the progress that banks and governments are making in developing truly internationally diversified banking markets and institutions. The data can also highlight trends in international lending and in the structuring of worldwide operations by financial institutions. Walter Bagehot, the renowned nineteenth-century economist, once stated that the characteristic danger of great nations is that they may at last fail from not comprehending the great institutions they have created. It is useful, therefore, to understand the structure and evolution of the banking organizations that play vital roles in the world economy. Such background aids in evaluating events as they unfold.

\section{HISTORICAL BACKGROUND}

For U.S. banks, the 1960s and 1970s were years of rapid growth in international banking. The few truly global ones, which had long before ventured abroad, refined their networks and penetrated foreign markets more deeply. Other large regional and money center banks also expanded their operations, though they largely confined their activities to foreign financial centers and to commercial lending and wholesale financial business.

Meanwhile (mostly in the 1970s), many smaller U.S. regional institutions began to recognize the benefits of a foreign presence, principally to accommodate and retain domestic customers whose activities were beginning to extend beyond U.S. borders. Some of these banks established full-service branches, typically in European cities, but most of them sought only "shell branches" in Caribbean centers as a means of gaining access to Eurodollar markets. ${ }^{1}$

Consequently, the number of U.S. banks having foreign branches began to grow. In late 1965, only 13 U.S. banks had foreign branches, and most of those had only a few; the branches' assets totaled less than $\$ 10$ billion. By 1970, 79 banks had foreign branches, with assets totaling $\$ 53$ billion. Ten years later, 159 banks - nearly every U.S. bank having assets of more than $\$ 2$ billion-had at least one foreign branch, the number of branches had grown to 787, and combined branch assets exceeded $\$ 340$ billion.

Before the 1960s, few U.S. banks owned subsidiaries abroad, and total subsidiary assets in 1965 were less than \$3 billion. During the 1970s, however, subsidiaries also began to grow, building assets to $\$ 39$ billion by 1975 and to more than $\$ 80$ billion by 1980 . They typically conducted commercial or merchant banking or pursued local retail business.

1. Shell branches are so named because they are merely booking centers. Bank personnel do not conduct operations on site at these branches, but rather book balances at these offices from other locations. 
By the early 1980s, strains from the rapid growth of international banking were beginning to show. Borrowers in many emerging economies were having difficulty servicing their debt, and the specter of losses loomed. By the end of the decade, despite efforts by creditor banks worldwide to postpone or avoid them, many of those losses were realized, requiring significant charge-offs and additional loss reserves. The threat of still further large losses on loans to developing countries did not disappear until the early 1990s, when improving domestic economic conditions and strong earnings enabled U.S. banks to charge off additional foreign loans and to put those problems behind them.

Banks of other countries-particularly European banks-have engaged in international banking for hundreds of years. For a time, they generally trailed the largest U.S. banks in creating worldwide branch networks. But during the late 1970s they, too, became more expansive and began to close the gap. Not surprisingly, considering the prominence of U.S. businesses and financial markets, much of the foreign bank growth was in the United States.

The resulting increase in the U.S. market share controlled by foreign banks, fueled by some notable acquisitions of U.S. banks, generated considerable political debate and in 1978 spurred the Congress to enact legislation intended to make more equitable a competitive environment seen to favor foreign banks. The legislation (the International Banking Act of 1978) was aimed at eliminating the advantages enjoyed by foreign banks and at strengthening the supervisory oversight of those banks' U.S. activities, not at barring their entry or at erecting barriers against them. Subsequently, although they had lost some advantages, the number of foreign banks operating in U.S. markets and their market share continued to grow-from 153 banks and 13 percent of U.S. domestic banking assets at the end of 1980 to 283 banks and 24 percent ten years later.

\section{STRUCTURAL FRAMEWORK FOR INTERNATIONAL BANKING}

The institutional structure for international banking by U.S. banks is in large part a reflection of efforts to restrain banking power. Throughout this country's history, government policy has sought to restrain concentration in banking and other financial activities. Until 1997, for example, U.S. banks generally were not allowed to branch across state lines (although, by then, their parent holding companies could own banks in different states). For much of this century, U.S. banks have also generally been barred from underwriting corporate securities and from conducting other financial activities typically permissible for foreign banks.

Although such restrictions helped diffuse financial power, they also, some observers argued, hindered U.S. banks from providing international banking services to U.S. customers and from competing effectively in foreign markets with institutions that offered a greater range of financial services. As early as 1919 these concerns led to enactment of section 25(a) of the Federal Reserve Act (the portion known as the "Edge Act") and, through limitedpurpose Edge corporations, to meaningful relief from restrictions on branching interstate and investing abroad. Although some of the structures that developed over the years to facilitate international banking by U.S. banks are unique to U.S. banking, the main types of offices used by U.S. banks and bank holding companies to engage in international banking are also used by foreign banks - namely, branches, separately incorporated subsidiaries, joint venture companies, and simple representative offices.

\section{Foreign Offices}

Foreign branch offices are the most important, and in most instances the preferred, vehicle through which U.S. banks provide international banking services, for several reasons. First, they are, legally, integral parts of the corporate bank and have the full authority to represent and commit the bank-an advantage in many commercial and interbank situations. For example, the lending limits imposed by a host country on the local branches of a foreign bank are ordinarily based on the bank's worldwide capital, not on some lower level of capital imputed from an individual branch's own balance sheet. ${ }^{2}$ Also, the activities of branches are typically more easily integrated into the internal reporting and control procedures of the bank than are the activities of other types of offices, and branches accommodate a more streamlined organizational structure.

Many U.S. banks also find it necessary to operate abroad through separately incorporated, separately capitalized foreign subsidiaries. Most of the subsidiaries are wholly owned by the U.S. banking parent; all are at least majority owned and controlled by the parent. Although a subsidiary's financial strength and

2. In an exception to this general practice, Argentina imposes prudential lending limits on foreign bank branches that are based on local paid-in capital, not on the parent bank's capital. 
reputation, and in many cases its operations, are closely tied to its parent's, in the legal sense a subsidiary could survive on its own. Banks (or bank holding companies) establish or acquire foreign subsidiaries for any of several reasons: ${ }^{3}$

- U.S. or foreign tax or banking laws favor operations through subsidiaries

- The host government does not permit foreign banks to have local branches

- The parent bank seeks consumer business in the foreign market or a local image, or it has other specialized business that is facilitated by separate incorporation

- U.S. laws prohibit branches from engaging in certain activities that subsidiaries may perform, for example, underwriting corporate debt

- Acquiring an established institution helps the purchaser gain an immediate, and perhaps sizable, presence in the market.

Limited liability is another reason for establishing separately incorporated subsidiaries. Although that is sometimes a consideration for banking organizations-for example, in the case of specialized leasing company subsidiaries-it is generally not an important factor in planning banking networks. Financial institutions depend on raising large sums daily, and they recognize that a good reputation is essential for long-term viability. The incentive to support ailing subsidiaries is strong, limited liability notwithstanding.

Banks also engage in international banking through foreign joint ventures. These foreign companies, in which the U.S. bank or bank holding company has a noncontrolling 20 percent to 50 percent investment, offer several advantages and serve the needs of certain banks. Investing banks can combine their expertise and resources while sharing the risks in what may be for them a relatively new business. Also, U.S. regulations allow banks to invest in a broader range of foreign activities if the investments do not represent controlling interests.

Foreign joint ventures were more popular in the 1970s, when many U.S. banks were beginning to enter international banking, than they are now. At that time the advantages of joint ventures were appealing, and banks sought partners both domestically and abroad. However, when the ventures encountered problems, as many eventually did, the U.S. banks were typically the only investors able to

3. James V. Houpt and Michael G. Martinson, Foreign Subsidiaries of U.S. Banking Organizations, Staff Studies 120 (Board of Governors of the Federal Reserve System, 1982). help. In virtually every case, they provided the assistance necessary to protect their reputations in financial markets, sometimes doing so at significant cost. Since the 1970s, joint ventures have been of little interest to U.S. banks, and they are not discussed further.

Some banks engage in international banking in some locales through simple representative offices. The principal role of the bank "representatives" that staff these offices is to promote the bank's interest in the local market-generating business, dealing with local authorities and customers, and providing information about local business conditions to the bank's other offices. Representative offices are not licensed or chartered and may not accept deposits or make loans. Indeed, they have no financial statements of their own, and they direct any business they generate to other offices or affiliates of the bank.

\section{U.S. Offices}

Although U.S. banking organizations conduct most of their international activities through foreign branches and subsidiaries, they also handle much international banking directly from domestic offices-the bank's head office, an Edge corporation, or an international banking facility. Banks need no foreign office to issue and process letters of credit, for example, or to purchase international loans, trade foreign exchange, take deposits from foreign sources, or place funds in foreign banks. For these transactions, banks can typically accommodate customers through their head offices and with the assistance of foreign correspondent banks.

Edge (and agreement) corporations are subsidiaries that enable banks to conduct international banking business outside their home states and to invest abroad in a wider range of activities than is otherwise permissible for U.S. banks. ${ }^{4}$ Banking and investing functions are almost always conducted by separate Edge corporations. Banking Edges are essentially limited-purpose banks; they may accept deposits and offer a full range of banking services, but the business must be linked to a foreign or international transaction. Nonbanking (or "investment") Edge corporations are U.S. subsidiaries through which banks hold most of their foreign subsidiaries and other foreign investments.

4. Edge corporations take their name from Senator Walter Edge of New Jersey, who sponsored the section 25(a) amendment to the Federal Reserve Act in 1919 that gave rise to these corporations. Agreement corporations are state-chartered companies that are granted the same powers as Edge corporations. 
International banking facilities (IBFs), which have existed only since 1981, have no separate organizational identity but are merely separate sets of accounts maintained by their establishing (or "host") banking offices. IBFs are attractive to banks for several reasons. First, their deposits are exempt from any reserve requirements and are not assessed for (nor are they covered by) federal deposit insurance. Also, in some states the earnings derived from balances booked in IBFs receive favorable state tax treatment. To qualify for placement in an IBF, a banking transaction must meet several tests to ensure that it is international and does not directly affect domestic financial markets. IBFs have been described as effectively being shell branches, similar to those in the Caribbean. The only difference is that IBF balances are assets or obligations of offices located in the United States rather than abroad.

\section{U.S. BANK INVOLVEMENT IN INTERNATIONAL BANKING MARKETS}

The state of international banking can be examined in two ways: (1) by looking at the number and size of offices of different types - for example, the assets of foreign branches, subsidiaries, and other foreign offices and the volume of internationally related credit extended directly from the head office, and (2) by reviewing data on total credit exposure to foreign parties, by country. Each approach has merits. The former, which is based on "structure" data, provides more information about, and therefore more insights into, the operational strategies of banks and the legal and regulatory framework in which they operate. By considering activities whenever an international link exists, even if the customer is not foreign, it also produces a broader measure than the second. Such a broader measure may be more appropriate because even loans to U.S. parties that are booked abroad may be booked there because they are financed with funds raised abroad. Structure data come from numerous sources, however, and reconciling the data can be difficult and lead to unexplained differences, even when the reporting forms are designed to be compatible. The "country exposure" approach is more systematic because it relies on a single, consolidated figure that reporting institutions themselves generate to measure their foreign credit and transfer risks.

This article reports both structure and country exposure data. The former are available over a longer period, and they identify the location and size of the foreign operations. The latter show where the credit and transfer risks lie, regardless of which office generated the assets and where they are booked.

\section{Extent of Operations}

When examining the organizational structure of international banking, a question arises about which financial statistic best characterizes the role and importance of each type of office. Amount of assets is an obvious possibility, as it covers all the activities of an office and is a traditional measure of bank size. However, the assets of an individual office can include significant intracompany transactions and may reflect mostly the bank's internal funding practices. Those balances are important to understanding a particular office's specific role, but they can also mislead, and they are excluded from the consolidated financial statements that the bank presents to investors and to the public at large.

Amount of deposits is another common measure, but it, too, is limited. For example, some foreign subsidiaries are not banks and, therefore, do not have deposits. Also, data on deposits cannot convey the growing importance to banks of securities transactions and off-balance-sheet derivatives activities.

A third measure, claims on unrelated parties, excludes dealings with affiliates. The figures for these assets for each type of office can be summed to produce a total that equals (conceptually) the consolidated assets of the parent. However, this measure considers only one side of the balance sheet and therefore understates the role of offices that raise funds and then transfer those funds to other offices of the parent or to its subsidiaries.

A full range of statistics and other information is needed to fully understand the importance and role of any office in a bank's network, of course, but that approach is beyond the scope of this article. The discussion here is based on the two asset measurestotal assets and claims on unrelated parties.

To place the importance of different types of offices in perspective, it helps to look at aggregate data on claims on unrelated parties. By that measure, U.S. banks and bank holding companies at the end of 1998 held an estimated $\$ 861$ billion of international banking assets through their U.S. and foreign offices (table 1). That figure represented about 15 percent of the assets of all U.S. banks and bank holding companies at the time. For some individual institutions, however, international banking accounts for most of their consolidated assets. 
1. International banking assets of U.S. insured commercial banks and bank holding companies, by type of office, selected years, 1980-98

Billions of dollars except as noted

\begin{tabular}{|c|c|c|c|c|c|c|c|c|}
\hline \multirow{2}{*}{ Type of office } & \multirow{2}{*}{1980} & \multirow{2}{*}{1985} & \multirow{2}{*}{1990} & \multirow{2}{*}{1995} & \multirow{2}{*}{1996} & \multirow{2}{*}{1997} & \multicolumn{2}{|c|}{1998} \\
\hline & & & & & & & Amount & Percent \\
\hline Domestic offices of U.S. banks & 61.8 & 142.2 & 78.1 & 65.4 & 75.2 & 89.4 & 80.8 & 9.4 \\
\hline $\mathrm{IBFs}^{1} \ldots \ldots \ldots \ldots \ldots \ldots$ & & 74.8 & 47.9 & 38.1 & 39.3 & 51.3 & 45.8 & 5.3 \\
\hline Other $^{2} \ldots \ldots \ldots \ldots \ldots \ldots$ & 61.8 & 67.4 & 30.2 & 27.3 & 35.9 & 38.1 & 35.0 & 4.1 \\
\hline Foreign branches 3,4 & 292.8 & 243.3 & 217.6 & 360.1 & 405.0 & 462.1 & 430.6 & 49.9 \\
\hline Foreign subsidiaries 4,5 & 64.0 & 88.7 & 136.7 & 223.5 & 254.1 & 264.8 & 338.8 & 39.5 \\
\hline Banking Edge and agreement & & & & & & & & \\
\hline corporations $\ldots \ldots \ldots \ldots$. & 13.6 & 7.9 & 7.1 & 7.9 & 7.7 & 12.0 & 10.5 & 1.2 \\
\hline $\mathrm{IBFs}^{1}$. & & 2.9 & 3.4 & 3.5 & 3.1 & 3.1 & 3.7 & .4 \\
\hline Other $^{2}$ & 13.6 & 5.0 & 3.7 & 4.4 & 4.6 & 8.9 & 6.8 & .8 \\
\hline Total & 432.2 & 482.1 & 439.5 & 656.9 & 742.1 & 828.2 & 860.6 & 100.0 \\
\hline
\end{tabular}

Note. Data are as of December 31 and cover only claims on unrelated parties. In this and subsequent tables, components may not sum to totals because of rounding.

1. International banking facilities (IBFs) were not authorized until December 1981.

2. Extensions of credit to foreign parties booked outside IBFs, plus the amount of international trade financing indicated by the amount of customers' liability on acceptances outstanding.
3. Covers foreign branches of only those banks that are members of the Federal Reserve System; at the end of 1998, member banks accounted for 98 percent of all foreign branch assets of U.S. banks.

4. Figures for 1995 and later years are reduced to reflect further FIN 39 netting by the head office or parent bank. See text note 5 .

5. Covers foreign subsidiaries held directly by bank holding companies and those held indirectly through banks or Edge corporations.

.. . Not applicable.

\section{Foreign Branches}

The number and assets of foreign branches of U.S. banks grew sharply throughout the 1960s and 1970s but then stagnated and declined in the 1980s as mounting problems with loans to developing countries dampened enthusiasm for foreign lending (table 2). Regional institutions, in particular, reassessed and restructured their international presence, and many withdrew from international banking altogether. This retrenchment, together with the large number of bank mergers in the past decade, has reduced the number of U.S. banks having foreign branches nearly one-half since the mid-1980s, to eighty-two banks at the end of 1998.

With fewer internationally active U.S. banks, the number of foreign branches also declined and did not surpass the peak levels of the mid-1980s until last year. The new level ( 935 branches) was reached only when both Citibank and BankBoston purchased Argentine banks and converted scores of acquired offices to branches of their own banks. At the end of 1998, these branches, together with Argentine branches previously established by the two banks, accounted for nearly one-quarter of all foreign branches of U.S. banks. That large share reflects both banks' long history in commercial and retail banking in Argentina and that nation's willingness to accommodate the banks' preference for branch offices.

Although foreign branch assets also dipped in the early 1990s, that amount has grown dramatically over the long term, emphasizing the relatively mod- est level of international banking activity that existed only a few decades ago. From a base of $\$ 10$ billion in 1965, the total assets of branches have increased more than seventyfold, reaching $\$ 705$ billion at the end of 1998. Even since 1993, branch assets have nearly doubled. Unlike the growth in earlier periods,

2. Foreign branches of U.S. insured commercial banks, selected years, 1955-98

Billions of dollars except as noted

\begin{tabular}{|c|c|c|c|c|}
\hline \multirow[b]{2}{*}{ Year } & \multirow{2}{*}{$\begin{array}{l}\text { Number of } \\
\text { banks with } \\
\text { foreign } \\
\text { branches }\end{array}$} & \multirow{2}{*}{$\begin{array}{l}\text { Number of } \\
\text { foreign } \\
\text { branches }\end{array}$} & \multicolumn{2}{|c|}{ Assets of foreign branches ${ }^{1}$} \\
\hline & & & $\begin{array}{c}\text { Adjusted total } \\
\text { assets }\end{array}$ & $\begin{array}{c}\text { Claims on } \\
\text { unrelated } \\
\text { parties }\end{array}$ \\
\hline 1955 & 7 & 115 & 2.0 & n.a. \\
\hline 1960 & 8 & 131 & 3.5 & n.a. \\
\hline 1965 & 13 & 211 & 9.8 & n.a. \\
\hline 1970 & 79 & 532 & 52.6 & n.a. \\
\hline 1975 & 126 & 762 & 162.7 & n.a. \\
\hline 1980 & 159 & 787 & 343.5 & 292.8 \\
\hline 1985 & 162 & 916 & 329.2 & 243.3 \\
\hline 1990 & 122 & 833 & 304.4 & 217.6 \\
\hline 1991 & 122 & 818 & 325.3 & 224.8 \\
\hline 1992 & 115 & 787 & 311.0 & 218.8 \\
\hline 1993 & 108 & 774 & 375.5 & 241.1 \\
\hline 1994 & 106 & 781 & 506.2 & 316.0 \\
\hline 1995 & 102 & 788 & 567.1 & 360.1 \\
\hline 1996 & 93 & 820 & 615.4 & 405.0 \\
\hline 1997 & 89 & 852 & 734.7 & 462.1 \\
\hline 1998 & 82 & 935 & 704.5 & 430.6 \\
\hline
\end{tabular}

NotE. Data are as of December 31. Covers foreign branches of banks that are members of the Federal Reserve System.

1. Figures for 1994 and later years are reduced to reflect further FIN 39 netting by the head office or parent bank. For 1998, the reduction was $\$ 63$ billion. See text note 5 .

n.a. Not available. 
1. Foreign branches of U.S. banks and foreign branch assets, by region, 1965-98

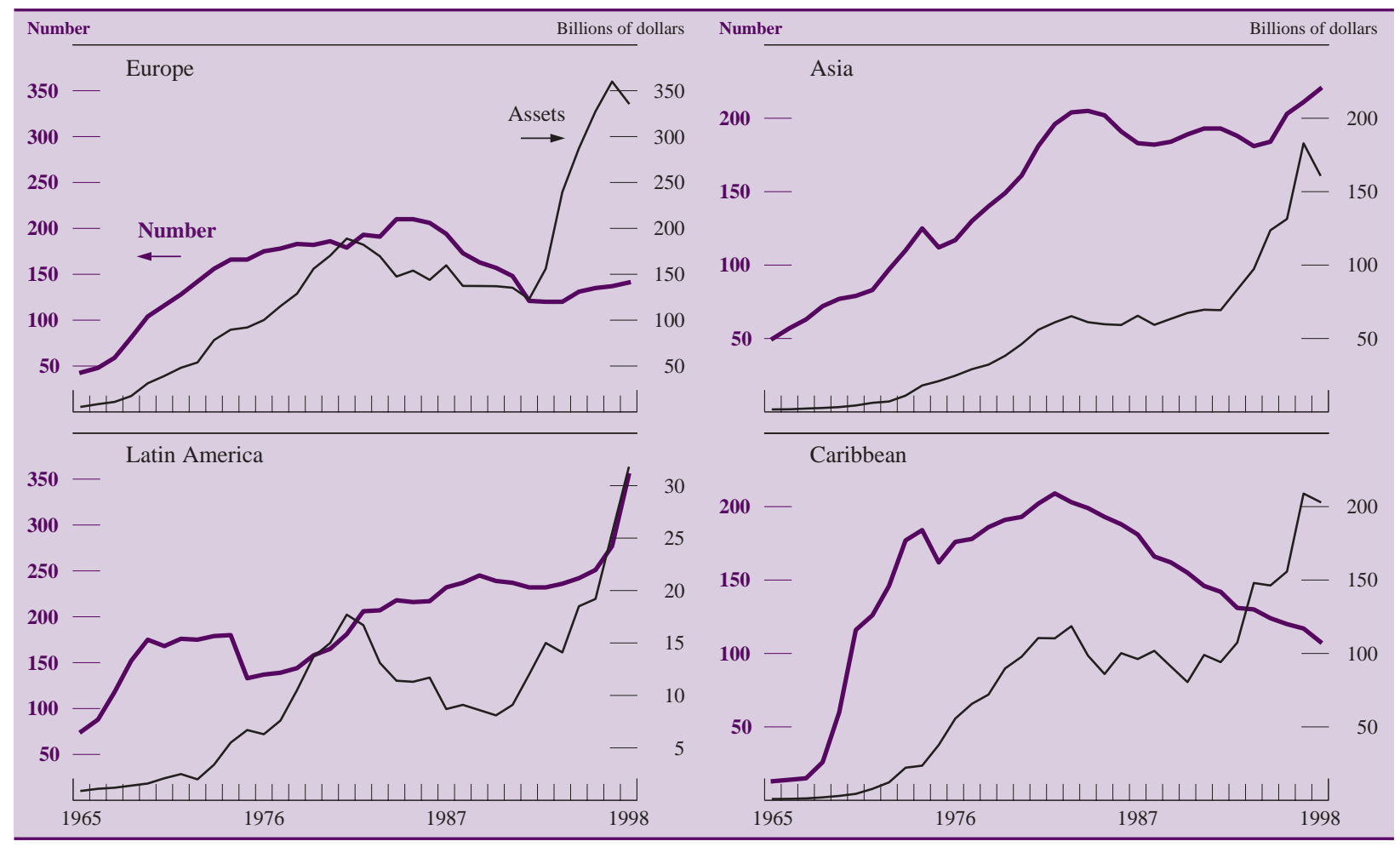

which was based in lending, much of the branch asset growth in recent years reflects trading activities and a 1994 accounting change pertaining to derivatives transactions. $^{5}$

The growth of branch activities has varied considerably by world region (chart 1, tables A.1 and A.2). Outside the United States, the major countries of

5. In 1994, banks implemented U.S. Financial Accounting Standards Board interpretation 39 (FIN 39), which clarified the degree to which they could net counterparty claims arising from trading and derivatives activities and ended a practice known as "grand slam netting." Institutions had been effectively netting their total gains on these activities with "offsetting" losses, regardless of counterparty. FIN 39 clarified that the netting of gains and losses was permissible only by individual counterparty and required institutions to report the result for each counterparty as either an asset or a liability. The revised approach more accurately reflects the results of an institution's trading and derivatives activities and the counterparty risks the activities represent, but it also increases the amount of consolidated assets reported by the bank. Moreover, the calculations can substantially increase the assets of individual offices that conduct these activities (particularly offices in London) because more netting among numerous counterparties is possible on a consolidated bankwide basis than is possible for a given office. As a result of their own (limited) netting abilities, foreign branches and subsidiaries of U.S. banks reported total trading assets (including the relevant revaluation gains) of $\$ 267$ billion at the end of 1998. Further netting by the head offices reduced that figure to $\$ 169$ billion (as shown in table 5). The assets for 1994 and later years shown in tables 1 and 2 have also been adjusted to reflect such nettings.
Europe (especially the United Kingdom) have had the largest, most developed, and most accessible financial markets. Mostly because of London's role in financial markets, but also because of the traditionally strong ties between Western Europe and the United States, the assets of branches in Europe far exceed those of branches in other regions.

From the late 1960s to the mid-1970s, European branches accounted for 60 percent to almost 80 percent of all foreign branch assets of U.S. banks. As branches in the Caribbean offshore centers, Singapore, and Japan began to grow, the relative importance of European branches (by that measure) declined. Since the early 1980s, the distribution of branch assets has changed little, with the European offices holding 44 percent at the end of 1998 and the Caribbean and Asian offices holding 26 percent and 21 percent respectively. Branches in Argentina and other Latin American countries accounted for most of the balance.

\section{Foreign Subsidiaries}

Although subsidiaries are generally smaller than branches in terms of assets, they are in most cases 
integral parts of a bank's international banking network. They supplement the parent's branch activities or extend its reach into local retail banking in ways not practical through branches. Through its Regulation K (International Banking Operations), the Federal Reserve Board requires that the activities of foreign subsidiaries be financial in nature, but within that stricture it permits a broad range of activities. In practice, most subsidiary activities have involved some form of traditional banking or lending. More recently, however, as the securities and trading activities of major U.S. banks have grown, so too have these activities of their foreign subsidiaries.

Foreign subsidiaries have grown rapidly in recent years: Their assets, including claims on affiliates, climbed from $\$ 7$ billion in 1970 to $\$ 81$ billion by 1980 , to $\$ 191$ billion by 1990 , and to $\$ 718$ billion by the end of 1998. As has been the case for foreign branches, Europe has been the most attractive location for subsidiaries, with those in the United Kingdom overshadowing those in other countries (table 3). Also like the growth of foreign branches, the growth of subsidiaries reflects London's role in international finance (as well as the United Kingdom's openness to U.S. banks).

Total assets provide an incomplete picture of foreign subsidiaries, however, because of the recent growth of trading activities-particularly in London-and the role subsidiaries play in their parents' networks. Overall, nearly half the total assets of foreign subsidiaries involve claims on related parties. As noted, tax laws-U.S. state and local laws as well as U.S. federal laws and international tax treaties-sometimes have the effect of encouraging banks to conduct business in subsidiaries rather than branch offices. A bank's past organizational structure in a country, which itself has been influenced by past and current tax and banking laws and regulations, also affects decisions regarding where to book transactions. Once staffed and operating, subsidiaries can be costly to dismantle even when changing circumstances favor a different approach.

Foreign subsidiaries vary widely in size, depending on their role. Some approach the size of large U.S. banks, when measured by total assets (including claims on affiliates). At the end of 1998, the 23 largest foreign subsidiaries (those having assets of more than $\$ 5$ billion, about 2 percent of all such subsidiaries) accounted for 68 percent of all foreign subsidiary assets. The nearly 800 subsidiaries having total assets of less than $\$ 100$ million (70 percent of all foreign subsidiaries) held less than 2 percent of total foreign subsidiary assets.
3. Foreign subsidiaries of U.S. banking organizations, by location of subsidiary, year-end 1998

Billions of dollars except as noted

\begin{tabular}{|c|c|c|c|c|c|}
\hline \multirow{2}{*}{ Location of subsidiary } & \multirow{2}{*}{ Number } & \multirow{2}{*}{ Percent } & \multicolumn{2}{|c|}{$\begin{array}{c}\text { Claims on } \\
\text { unrelated parties }\end{array}$} & \multirow{2}{*}{$\begin{array}{l}\text { Total } \\
\text { assets }\end{array}$} \\
\hline & & & Amount & Percent & \\
\hline Europe & 327 & 28.9 & 209.4 & 56.0 & 477.6 \\
\hline Belgium & 8 & .7 & 2.5 & .7 & 2.6 \\
\hline Czech Republic & 5 & 4 & 1.4 & .4 & 1.6 \\
\hline France ........ & 26 & 2.3 & 5.8 & 1.5 & 12.1 \\
\hline German & 24 & 2.1 & 21.8 & 5.8 & 34.7 \\
\hline Luxembourg & 19 & 1.7 & 2.1 & .6 & 8.0 \\
\hline Poland . & 6 & .5 & 1.8 & .5 & 2.1 \\
\hline Spain & 14 & 1.2 & 13.8 & 3.7 & 14.9 \\
\hline Switzerland & 23 & 2.0 & 13.5 & 3.6 & 19.6 \\
\hline United Kingdom & 110 & 9.7 & 136.3 & 36.4 & 358.3 \\
\hline Other . & 92 & 8.1 & 10.5 & 2.8 & 23.7 \\
\hline Offshore banking centers & 211 & 18.6 & 25.3 & 6.8 & 66.6 \\
\hline Bahamas & 19 & 1.7 & 3.7 & 1.0 & 5.7 \\
\hline Cayman Islands & 106 & 9.4 & 4.1 & 1.1 & 26.5 \\
\hline Channel Islands & 59 & 5.2 & 6.3 & 1.7 & 18.7 \\
\hline Singapore . & 27 & 2.4 & 11.2 & 3.0 & 15.7 \\
\hline Latin America & 238 & 21.0 & 28.0 & 7.5 & 40.5 \\
\hline Brazil & 57 & 5.0 & 12.0 & 3.2 & 19.1 \\
\hline Chile & 29 & 2.6 & 2.9 & .8 & 4.3 \\
\hline Colombia & 12 & 1.1 & 1.5 & .4 & 1.8 \\
\hline Mexico .. & 32 & 2.8 & 8.1 & 2.2 & 10.6 \\
\hline Other .. & 108 & 9.5 & 3.5 & .9 & 4.7 \\
\hline Asia/Pacific & 151 & 13.3 & 40.3 & 10.8 & 46.6 \\
\hline Hong Kong & 64 & 5.6 & 9.0 & 2.4 & 11.6 \\
\hline Japan & 21 & 1.9 & 24.4 & 6.5 & 26.3 \\
\hline Malaysia & 11 & 1.0 & 4.9 & 1.3 & 5.2 \\
\hline Other . & 55 & 4.9 & 2.0 & .5 & 3.4 \\
\hline Middle East & 8 & .7 & 13.3 & 3.6 & 13.4 \\
\hline Africa & 12 & 1.1 & .7 & .2 & 1.0 \\
\hline Australia . & 31 & 2.7 & 21.7 & 5.8 & 25.9 \\
\hline Canada & 36 & 3.2 & 17.3 & 4.6 & 20.9 \\
\hline U.S. territories and other & 60 & 5.3 & 8.6 & 2.3 & 9.8 \\
\hline United States ${ }^{1}$ & 59 & 5.2 & 9.4 & 2.5 & 15.6 \\
\hline Total & 1,133 & 100.0 & $373.9^{2}$ & 100.0 & 717.9 \\
\hline
\end{tabular}

1. Covers companies that are regulated as foreign subsidiaries by the Federal Reserve even though they are domiciled in the United States. These companies are subject to the limitations and conditions of Regulation $\mathrm{K}$, which requires that their activities be of a foreign or international nature. Many of them are leasing and investment companies.

2. Amount differs from the amount shown in table 1 because the latter figure was reduced by the estimated effect on subsidiaries of FIN 39.

\section{Edge Corporations}

The initial purpose for banking Edge corporations was to enable banks located outside New York State to gain a banking presence in New York City-a near-necessity for conducting international banking and for trading in foreign exchange; without such subsidiaries, past restrictions on interstate branching would have prevented non-New York banks from operating an international banking business in the New York market. During the 1980s, in particular, U.S. and foreign banks also used Edge corporations to expand beyond their home states into regional 
financial centers such as Miami, Chicago, and San Francisco.

The recent removal of federal interstate branching restrictions would seem to undermine much of the continuing appeal of banking Edge corporations, and, indeed, their relative role in international banking has declined. Nevertheless, more than thirty corporations remain, operating mostly in New York and Miami. At the end of 1998, they held $\$ 18$ billion in assets (including claims on affiliates), roughly their size throughout the 1980s. Whereas banking Edges extend the geographic reach of their parents, nonbanking, or "investment," Edges expand the kinds of companies in which their parent banks may invest. By law, U.S. banks may invest abroad only in other banks. By investing indirectly through Edge corporations, they may invest in virtually any type of foreign company, provided it conducts no business in the United States except that which is incidental to its foreign or international activities. (Through regulation, however, the foreign subsidiaries of a bank's Edge corporations are restricted to financial activities, as are foreign subsidiaries owned directly by bank holding companies, that is, not through a subsidiary bank.) At the end of 1998, 70 percent of the assets of all foreign subsidiaries of U.S. banking organizations were owned through Edge corporations.

\section{International Banking Facilities}

International banking facilities were popular from the time their creation was authorized in 1981, and soon 225 U.S. banking institutions had established such facilities, placing more than $\$ 60$ billion in them. However, their early growth was simply the result of a transfer of eligible credits within banks. After peaking at $\$ 79$ billion in 1984, the IBF balances of U.S. banks declined almost steadily, to $\$ 46$ billion at the end of 1998, as regional U.S. banks withdrew from foreign lending. Because of the typically international focus of their business, U.S. branches and agencies of foreign banks (discussed later) make much greater use of these facilities, holding $\$ 169$ billion in them at the end of 1998.

\section{Country Exposure}

Data on the extent and size of the international operations of U.S. banks offer one perspective on growth but provide no information on the nationality or type of foreign borrower. U.S. banks book many foreign loans in the United States, in offshore centers, and in countries different from those of the borrowers. They also extend loans denominated in currencies other than the currency of the borrower's home country. Lending to foreign parties creates "country risk" and also, depending on the currency, "transfer risk." 6

\section{Monitoring Country Exposure}

To monitor country risk and transfer risk, U.S. banking agencies have for more than two decades collected information from internationally active banks about the domicile and nature of their foreign borrowers. The information is collected through the quarterly Country Exposure Lending Survey and is published quarterly in the E.16 statistical release of the Federal Financial Institutions Examination Council. Aggregate data from the survey, along with data from similar surveys by foreign authorities in most other major countries, are sent to the Bank for International Settlements (BIS), which then compiles data on international lending by banks worldwide. The worldwide figures indicate that U.S. banks account for about 10 percent of international lending by banks in BIS reporting countries to parties in non-BIS reporting countries. ${ }^{7}$ That share is similar to the share held by French and Japanese banks and is materially smaller than the share held by German banks.

Until recently, the supervisory emphasis in evaluating country and transfer risks was on cross-border lending and on lending by local offices in a currency other than that of the host country. This emphasis reflected the view that credit extended in a foreign currency to local borrowers by local offices was exposed to many of the same risks as cross-border loans. Credits in local currencies funded locally were a lesser concern, as the host country could, in principle, always meet local currency demands, even if the cost was rising inflation rates. ${ }^{8}$

By the mid-1990s, the role of U.S. dollars in retail and business transactions abroad had become more

6. Country risk comprises all the risks that arise from the economic, social, legal, and political conditions of a foreign country that may have favorable or adverse consequences for loans (or investments) by foreigners to parties in that country. Transfer risk refers to the possibility that a country will be unable to provide local borrowers with sufficient access to foreign currencies that they can meet foreign obligations denominated in those currencies.

7. BIS reporting countries are the G-10 countries, Austria, Denmark, Finland, Ireland, Norway, and Spain; non-BIS reporting countries are essentially the nonindustrial countries.

8. However, local currency credits extended in excess of local currency liabilities, that is, funded with foreign currency or offshore borrowing, were included in measures of transfer risk. 
prominent. Local dollar markets developed in some countries, and the risks associated with foreign currency credits in those countries began to resemble the risks associated with other local loans rather than those characteristic of cross-border credits. The U.S. country exposure survey was changed to take these developments into account. Rather than net local currency positions, the banking agencies now consider net local country positions, that is, the amount of credit extended to local parties relative to the amount raised from them. The change has been meaningful in certain cases, particularly in relation to Argentina, but has had little effect on reported figures overall.

Since 1997, the Federal Reserve has also monitored U.S. bank exposures to foreign counterparties arising from unrealized gains from foreign exchange transactions and derivatives products. ${ }^{9}$ Although these exposures have always been an element of transfer risk, they have increased significantly in recent years along with the growth of the underlying activities. With the addition of this information and the reporting change described in the preceding paragraph, the supervisory measure of transfer risk has become the sum of cross-border claims, net local country claims, and claims resulting from revaluation gains.

The need to monitor exposures arising from revaluation gains was demonstrated following Indonesia's currency crisis in 1997. In lending to Indonesian borrowers, some banks had attempted to reduce or eliminate their currency exposures by hedging the risk through contracts with local institutions, which in turn committed to paying dollars in the future at a fixed rate of exchange. As the country's financial and economic problems grew, the U.S. dollar value of its currency, the rupiah, plunged, as did the dollar value of the U.S. banks' rupiah-denominated loans. However, the offsetting gains on the hedging contracts also increased the credit exposure of U.S. banks to Indonesian counterparties. Unfortunately, many of these counterparties were also weakened by financial and economic conditions in Indonesia and defaulted on their obligations to U.S. banks. The episode highlights the importance of monitoring counterparty exposures under relevant stress scenarios.

9. When trades and derivatives transactions are initiated, by definition they are done at market rates, with no economic gain or loss to either party. Immediately thereafter, however, market rates and prices begin to change, and one party benefits. As this happens, the party benefiting incurs a risk that the other party will default, causing losses just as if the underlying transaction had been a loan.

\section{Borrower Nationality}

U.S. bank claims involving transfer risk amounted to $\$ 516$ billion at the end of 1998 (table 4). Over the years, claims on borrowers residing in industrial countries have been far greater than claims on borrowers in any other group of countries, mainly because of the importance of the industrial economies in global economic activity, the prominence of their financial markets (especially London), and the relatively strong credit ratings of the countries and their major banks and corporations. Claims on parties in the G-10 and other developed countries at the end of 1998 , totaling $\$ 379$ billion, represented nearly threefourths of all transfer risk held by U.S. banks and have consistently accounted for roughly half or more of that risk. By the end of 1998, roughly one-third of this dollar value was related to trading and derivatives transactions.

U.S. bank transfer risk claims on borrowers in Latin American and Caribbean countries declined sharply over 1988-91 as the region's foreign debt payment problems became severe and widespread. From a peak of $\$ 91$ billion in 1984, including claims on Brazil and Mexico of roughly $\$ 27$ billion each, U.S. bank exposure to the region dropped as low as $\$ 38$ billion in 1991 before rising to the current level (\$66 billion). Relative to the total capital of the lending banks, exposure to Latin American and Caribbean countries has declined even further. For large U.S. money center banks, which hold more than 70 percent of all U.S. bank claims on the region, the amount of transfer risk exposure equals roughly onequarter of their combined capital accounts. In the early and mid-1980s, that figure was well over 100 percent.

Transfer risk claims of U.S. banks on emerging Asian economies followed a similar track, declining from a peak of $\$ 45$ billion in 1983 to a low of $\$ 22$ billion in 1989. By 1993, exposures were again growing rapidly, building to a peak of $\$ 55$ billion in 1997, including $\$ 11$ billion of revaluation gains on foreign exchange and derivatives contracts. U.S. banks were not alone in increasing their exposures, as Japanese and European banks were particularly active in providing new financing. Most of the U.S. bank funding (like most international lending in general) was short term, however, and bank exposures fell sharply following the Asian market problems that began that year. By the end of 1998, transfer risk claims of U.S. banks on these countries had fallen to $\$ 36$ billion, largely as a result of asset sales and charge-offs. 
4. Country exposure of U.S. insured commercial banks, as measured by transfer risk, selected years, 1978-98 Billions of dollars

\begin{tabular}{|c|c|c|c|c|c|c|c|c|c|c|c|}
\hline \multirow[b]{2}{*}{ Country of borrower or guarantor } & \multicolumn{7}{|c|}{ Transfer risk claims } & \multicolumn{4}{|c|}{ Composition of transfer risk for 1998} \\
\hline & 1978 & 1983 & 1988 & 1993 & 1996 & 1997 & 1998 & $\begin{array}{c}\text { Cross- } \\
\text { border } \\
\text { exposure }\end{array}$ & $\begin{array}{c}\text { Revaluation } \\
\text { gains }\end{array}$ & $\begin{array}{l}\text { Net local } \\
\text { country } \\
\text { claims }\end{array}$ & $\begin{array}{l}\text { Total } \\
\text { transfer } \\
\text { risk } \\
\text { claims }\end{array}$ \\
\hline G-10 and Switzerland & 100.2 & 183.0 & 169.7 & 155.4 & 174.3 & 263.4 & 318.3 & 203.3 & 94.8 & 20.2 & 318.3 \\
\hline Non-G-10 developed countries & 20.4 & 45.8 & 27.5 & 29.3 & 43.9 & 62.7 & 60.9 & 35.1 & 15.4 & 10.4 & 60.9 \\
\hline $\begin{array}{c}\text { Eastern Europe } \ldots \ldots \ldots \ldots \\
\text { Bulgaria } \ldots \ldots \ldots \ldots \ldots \\
\text { Czech Republic } \ldots \ldots \ldots \\
\text { Hungary } \ldots \ldots \ldots \ldots \ldots \ldots \\
\text { Poland } \ldots \ldots \ldots \ldots \ldots \ldots \ldots \\
\text { Russia } \ldots \ldots \ldots \ldots \ldots \ldots \ldots \ldots \\
\text { Other } \ldots \ldots \ldots \ldots \ldots \ldots \ldots \ldots \\
\end{array}$ & $\begin{array}{r}5.8 \\
.6 \\
.2 \\
.8 \\
1.2 \\
1.2 \\
1.8\end{array}$ & $\begin{array}{r}4.6 \\
.1 \\
.2 \\
.9 \\
.9 \\
.1 \\
2.4\end{array}$ & $\begin{array}{r}3.1 \\
.1 \\
.0 \\
.3 \\
.3 \\
.5 \\
1.9\end{array}$ & $\begin{array}{r}1.5 \\
.1 \\
.0 \\
.4 \\
.4 \\
.3 \\
.3\end{array}$ & $\begin{array}{r}7.1 \\
.2 \\
1.2 \\
.7 \\
1.0 \\
3.3 \\
.7\end{array}$ & $\begin{array}{r}9.1 \\
.2 \\
.6 \\
.5 \\
.9 \\
5.8 \\
1.1\end{array}$ & $\begin{array}{r}4.9 \\
.1 \\
.7 \\
.7 \\
1.7 \\
.9 \\
.8\end{array}$ & $\begin{array}{r}4.3 \\
.1 \\
.5 \\
.5 \\
1.6 \\
.8 \\
.8\end{array}$ & $\begin{array}{l}.5 \\
.0 \\
.2 \\
.2 \\
* . \\
.1 \\
.0\end{array}$ & $\begin{array}{l}.1 \\
.0 \\
.0 \\
.0 \\
.1 \\
* \\
.0\end{array}$ & $\begin{array}{r}4.9 \\
.1 \\
.7 \\
.7 \\
1.7 \\
.9 \\
.8\end{array}$ \\
\hline 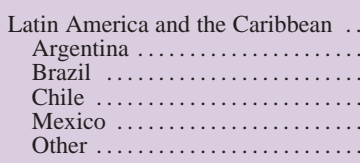 & $\begin{array}{r}44.9 \\
2.6 \\
14.2 \\
1.4 \\
10.3 \\
16.4\end{array}$ & $\begin{array}{r}87.5 \\
9.1 \\
24.1 \\
6.1 \\
25.4 \\
22.8\end{array}$ & $\begin{array}{r}67.1 \\
8.2 \\
22.0 \\
5.0 \\
17.7 \\
14.2\end{array}$ & $\begin{array}{r}50.1 \\
8.7 \\
9.9 \\
4.1 \\
17.6 \\
9.8\end{array}$ & $\begin{array}{r}69.0 \\
11.8 \\
22.8 \\
7.6 \\
14.8 \\
12.0\end{array}$ & $\begin{array}{r}72.5 \\
11.6 \\
23.2 \\
7.0 \\
16.4 \\
14.3\end{array}$ & $\begin{array}{r}66.5 \\
11.0 \\
17.6 \\
5.7 \\
18.2 \\
14.0\end{array}$ & $\begin{array}{r}55.1 \\
8.5 \\
14.1 \\
3.9 \\
16.1 \\
12.5\end{array}$ & $\begin{array}{r}2.3 \\
.5 \\
.4 \\
.1 \\
1.0 \\
.3\end{array}$ & $\begin{array}{l}9.1 \\
2.0 \\
3.2 \\
1.7 \\
1.2 \\
1.0\end{array}$ & $\begin{array}{r}66.5 \\
11.0 \\
17.6 \\
5.7 \\
18.2 \\
14.0\end{array}$ \\
\hline 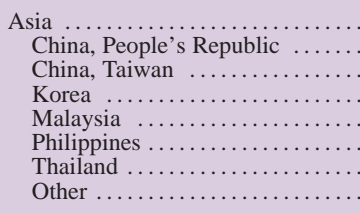 & $\begin{array}{c}22.9 \\
* \\
3.2 \\
4.3 \\
.8 \\
3.0 \\
1.4 \\
10.2\end{array}$ & $\begin{array}{r}44.5 \\
1.4 \\
4.9 \\
13.1 \\
2.1 \\
5.9 \\
2.8 \\
14.3\end{array}$ & $\begin{array}{r}22.5 \\
.6 \\
3.0 \\
6.4 \\
.6 \\
4.1 \\
1.3 \\
6.5\end{array}$ & $\begin{array}{r}31.4 \\
8 \\
4.1 \\
8.6 \\
2.0 \\
2.1 \\
3.1 \\
10.7\end{array}$ & $\begin{array}{r}50.8 \\
2.6 \\
5.2 \\
16.5 \\
2.9 \\
4.3 \\
6.5 \\
12.8\end{array}$ & $\begin{array}{r}54.9 \\
3.1 \\
4.1 \\
21.4 \\
3.4 \\
2.5 \\
6.0 \\
14.4\end{array}$ & $\begin{array}{r}35.8 \\
1.8 \\
3.6 \\
12.9 \\
2.1 \\
2.2 \\
2.9 \\
10.3\end{array}$ & $\begin{array}{r}23.4 \\
1.2 \\
2.7 \\
7.8 \\
.7 \\
1.6 \\
.9 \\
8.5\end{array}$ & $\begin{array}{r}5.1 \\
.4 \\
.2 \\
1.9 \\
.2 \\
.1 \\
.7 \\
1.6\end{array}$ & $\begin{array}{r}7.3 \\
.3 \\
.7 \\
3.1 \\
1.2 \\
.5 \\
1.3 \\
.2\end{array}$ & $\begin{array}{r}35.8 \\
1.8 \\
3.6 \\
12.9 \\
2.1 \\
2.2 \\
2.9 \\
10.3\end{array}$ \\
\hline Africa & 5.2 & 7.3 & 2.7 & 1.3 & 1.4 & 1.7 & 1.6 & 1.2 & .2 & .2 & 1.6 \\
\hline Offshore banking centers & 7.5 & 15.9 & 7.8 & 14.3 & 23.6 & 31.5 & 23.2 & 18.0 & 3.9 & 1.3 & 23.2 \\
\hline $\begin{array}{c}\text { International and regional } \\
\text { organizations } \ldots . . . . . .\end{array}$ & .4 & 1.0 & 1.6 & 1.3 & 1.1 & 3.5 & 5.1 & 2.6 & 2.5 & .0 & 5.1 \\
\hline Total & 207.4 & 389.6 & 301.8 & 284.4 & 371.2 & 499.2 & 516.3 & 342.9 & 124.8 & 48.6 & 516.3 \\
\hline
\end{tabular}

*Less than $\$ 50$ million.

U.S. bank lending in Eastern Europe has increased since the removal of the Berlin Wall, but transfer risk claims remain small ( $\$ 4.9$ billion at the end of 1998). Claims on Russia peaked at $\$ 5.8$ billion in 1997 but fell to $\$ 0.9$ billion by the end of 1998 after the country announced a moratorium on public-sector debt.

Although of lesser concern to supervisors, foreign bank lending in local currencies of funds raised locally has also grown in the 1990s. Such lending totaled $\$ 314.1$ billion at the end of 1998 , compared with $\$ 140.2$ billion at the end of 1990 . (These loans are reflected only partially in table 4 , under "Net local country claims.")

\section{Concentration among U.S. Lenders}

Mergers and acquisitions among large U.S. banking organizations since the mid-1980s have concentrated foreign lending among fewer U.S. banks. At the end of 1998, for example, a separately monitored group of six large money center banks held 83 percent of all transfer risk claims of U.S. banks. In 1986 that group consisted of nine banks, but it held only 58 percent of all such claims. A common statistic for measuring market concentration is the Herfindahl-Hirschman index, which does so by summing the squared market shares of participating institutions. From 1986 to 1998, according to Federal Reserve staff calculations, the index more than doubled, rising from 800 to $1623 .{ }^{10}$

\section{Trading and Derivatives Activities}

As noted, traditional asset-based measures can be misleading as a gauge of the scale and scope of today's large, complex banking organizations. The inadequacy of such measures is due in large part to the growing importance of securities markets and related trading and derivatives activities. Rather than extending and funding loans in traditional ways and thereby increasing their assets, many large commer-

10. For reference (though not applicable to this case), the U.S. Department of Justice defines a market as unconcentrated if the index is less than 1000 and highly concentrated if it is greater than 1800 . Otherwise, the market is considered to be "moderately" concentrated. 
cial banks (those in the United States, in particular) are seeking more and more to securitize and sell pools of loans to investors, and then to service the assets that they and other financial institutions have sold. Securitizing and selling loans minimizes asset growth, frees funds for additional lending, and may contribute to more efficient use of bank capital.

In the process of originating and securitizing assets, managing their own market exposures, providing financial services to customers, and pursuing market opportunities, banks are increasing their volume of off-balance-sheet transactions. Most of these activities, in turn, involve trading and derivatives activities and can also create additional needs for foreign offices.

Throughout the 1990s, trading assets increased rather steadily as a share of all U.S. commercial bank assets, rising from 2.0 percent at the end of 1990 to 5.2 percent ( $\$ 285$ billion) at the end of 1998 . More than 60 percent of those assets were booked abroad, principally in London but also, notably, in Tokyo and Singapore. Indeed, as indicated earlier, much of the recent growth of foreign branch and subsidiary assets has been due to the higher level of trading activities.

Nearly all the derivatives transactions of U.S. banks (95 percent) are managed within the trading function, and much of the activity heavily involves overseas offices. Nearly all the transactions (97 percent) are based on interest rate and foreign exchange rate contracts, with interest rate contracts commanding a dominant and growing share.

By a common measure-notional value (the face value of financial instruments upon which counterparty payments are based) - the derivatives activities of U.S. banks have grown markedly in recent years, from $\$ 6.8$ trillion at the beginning of the decade to $\$ 33.0$ trillion at the end of 1998 . Last year, notional values rose 32 percent because of soaring volumes in the third quarter as institutions adjusted their exposures after Russia's default and the near failure of Long-Term Capital Management, a large, highly leveraged hedge fund. In each of the following two quarters (through March 1999), however, notional values declined slightly, the first consecutive quarterly declines in this measure during the ten years for which data are available.

Notional values dramatically overstate the economic significance and risks these transactions present, however. Another measure-fair value (the estimated replacement costs of the contracts)—often serves better and is typically much smaller than the notional value of a derivatives portfolio $(0.5$ percent to 2.0 percent). If the amounts U.S. banks owe to or are owed by individual counterparties on derivatives transactions are netted on a bilateral basis consistent with FIN 39, the fair value of all derivatives transactions of U.S. banks totaled $\$ 173$ billion at the end of 1998 , or 0.5 percent of the total notional value. Trading and derivatives activities are heavily concentrated among the large money center banks, increasingly the same institutions that are most active abroad (table 5).

\section{FOREIGN BANK PARTICIPATION IN U.S. BANKING MARKETS}

The large and open economy of the United States, combined with the key role of its currency in world markets, has attracted foreign banks and investors to this country throughout its history. British merchant banks financed much of the trade with the colonies and established offices here in the mid-1700s. Other foreign banks operated formal banking agencies in New York shortly after the Civil War. Their efforts and capital were especially helpful in financing the growth of the U.S. railroads.

In recent decades, the U.S. banking assets of foreign banks have grown rapidly, climbing from \$27 billion and 3.6 percent of U.S.-booked commercial banking assets in 1972 to $\$ 1.1$ trillion and a 23 percent market share at the end of 1998 (table 6). Most of these assets-around 80 percent-are held in foreign bank branches and agencies located in the United States. ${ }^{11}$

As have U.S. bank holding companies, many foreign banks have also established or acquired U.S. nonbank financial companies, such as leasing and finance companies, and U.S. securities subsidiaries,

11. The assets of U.S. branches and agencies of foreign banks exclude substantial other assets that are managed by these offices but are booked in the Caribbean. U.S. agencies of foreign banks are similar to branch offices, except that, unlike branches, agencies have limited or no deposit-taking powers. Rather than providing funds to borrowers by granting the borrower a deposit to draw upon, an agency issues the borrower a "credit balance." In that context, deposits and credit balances are much the same. However, branches may also issue deposits (for example, CDs) to investors and other parties with whom they have no other relationship. Generally, agencies may not do that and must rely on other types of borrowing to fund their activities. Their credit balances must be "incidental to or [arise from] the exercise of other lawful banking powers." In practice, the differences between branches and agencies are often subtle. Both types of offices are integral parts of their parents; both have lending powers that are based on the capital of the consolidated bank; and the Federal Reserve treats the credit balances of the agencies as deposits in determining reserve requirements. Branches and agencies established since 1991 have not been permitted to accept domestic retail deposits or to obtain FDIC insurance; a small number of foreign bank branches established before 1991 may accept FDIC-insured deposits. 
5. Trading, derivatives, and international activities of selected U.S. insured commercial banks, year-end 1998 Billions of dollars except as noted

\begin{tabular}{|c|c|c|c|c|c|c|c|}
\hline \multirow{3}{*}{ Bank } & \multicolumn{3}{|c|}{ Trading assets } & \multicolumn{3}{|c|}{ Derivatives activities } & \multirow{3}{*}{$\begin{array}{l}\text { International } \\
\text { assets as a } \\
\text { percentage o } \\
\text { consolidated } \\
\text { assets }\end{array}$} \\
\hline & \multirow{2}{*}{ Domestic offices } & \multirow{2}{*}{ Foreign offices } & \multirow{2}{*}{ Total } & \multirow{2}{*}{ Notional value } & \multicolumn{2}{|c|}{ Revaluation gain } & \\
\hline & & & & & Domestic offices & Foreign offices & \\
\hline Morgan Guaranty Trust Company & 37.8 & 53.0 & 90.8 & $8,653.6$ & 25.5 & 23.6 & 53.6 \\
\hline Chase Manhattan Bank .......... & 11.2 & 37.7 & 48.9 & $10,261.5$ & 7.2 & 25.5 & 36.4 \\
\hline Bankers Trust Company & 7.7 & 32.3 & 40.0 & $2,524.1$ & 3.3 & 14.3 & 62.5 \\
\hline Citibank NA $\ldots \ldots \ldots$..... & 5.5 & 26.2 & 31.7 & $3,625.3$ & 5.2 & 20.6 & 68.4 \\
\hline NationsBank NA ${ }^{1} \ldots \ldots . .$. & 21.3 & .6 & 21.9 & $2,700.9$ & 7.1 & .4 & 4.4 \\
\hline Bank of America NT\&SA ${ }^{1}$ & 7.6 & 10.5 & 18.1 & $1,870.2$ & 5.7 & 3.7 & 24.9 \\
\hline First National Bank of Chicago & 2.7 & 4.9 & 7.6 & $1,421.3$ & 1.8 & 4.3 & 22.4 \\
\hline First Union NB ............. & 7.0 & .0 & 7.0 & 268.9 & 1.7 & .0 & 9.0 \\
\hline Republic NB of NY & 2.7 & 1.5 & 4.2 & 194.9 & 1.9 & .5 & 31.0 \\
\hline BankBoston NA ... & 2.0 & 1.1 & 3.1 & 147.9 & 1.7 & .4 & 30.7 \\
\hline State Street B\&TC & 1.5 & .1 & 1.6 & 139.2 & 1.2 & .0 & 26.3 \\
\hline Bank of New York & 1.3 & .3 & 1.6 & 274.6 & 1.0 & .3 & 21.7 \\
\hline Subtotal & 108.2 & 168.2 & 276.4 & $32,082.4$ & 63.2 & 93.4 & 32.9 \\
\hline All other banks & 8.5 & .3 & 8.7 & 918.2 & 2.6 & .3 & 1.6 \\
\hline Total & 116.7 & 168.5 & 285.1 & $33,000.6$ & 65.8 & 93.7 & $12.9^{2}$ \\
\hline
\end{tabular}

1. These banks are now controlled by a single bank holding company, BankAmerica Corporation.

subject to the restrictions of section 20 of the GlassSteagall Act. ${ }^{12}$ At the end of 1998, these nonbank companies held assets exceeding $\$ 800$ billion, with section 20 and similar U.S. securities affiliates accounting for more than $\$ 500$ billion of the total.

Before the 1970s, almost all the foreign banks having offices in the United States were large banks from major industrial nations or were the largest or second-largest banks in their home countries; by the end of 1975, 20 percent of the foreign banks having U.S. banking offices were not among the world's top 500 , and by 1985 that figure had increased to 34 percent. The number of foreign banks with offices in the United States also rose during the 1980s, from 153 at the beginning of the decade and to a peak of 294 at the end of 1991.

Much of the buildup to 1991 was driven by the entry of more than two dozen additional Japanese banks in the preceding four years. Those banks raised

12. Section 20 of the Banking Act of 1933 (part of the GlassSteagall Act) prohibits a bank from being affiliated with a company engaged "principally" in underwriting or dealing in securities. In 1989 the Federal Reserve interpreted that provision as permitting holding companies to own securities affiliates that engage in otherwise impermissible securities activities if the revenues from those activities did not account for more than 10 percent of the affiliate's total revenues. In 1997, the percentage limitation was raised to 25 percent. The securities affiliates that U.S. bank holding companies established following this interpretation are referred to as "section 20" subsidiaries. By regulation, most of their activities must involve trading and dealing in U.S. government securities and other financial instruments also permissible to U.S. banks. Foreign banks are also allowed to own such companies.
Japan's total to 55, the largest number, by far, for any nationality. Japan's economic problems in the 1990s, however, led to a significant retrenchment in the international activities of its banks and to a reversal of their earlier U.S. growth. By the end of 1998, the number of Japanese banks had dropped to 35 and their U.S. operations were much smaller than they had been ten years earlier.

The number of European banks with U.S. offices also declined during the 1990s, from a peak of 103 in 1989 to 81 at the close of 1998 . However, this decline was due more to mergers and acquisitions among banks throughout the continent than to any strategic retreat from U.S. markets.

In structuring their activities, foreign banks generally have the same choices regarding the types of

6. Assets of U.S. banking offices of foreign banks, selected years, 1975-98

Billions of dollars except as noted

\begin{tabular}{c|c|c|c|c|c}
\hline Year & $\begin{array}{c}\text { Branches } \\
\text { and } \\
\text { agencies }\end{array}$ & $\begin{array}{c}\text { Commercial } \\
\text { banks } \\
\text { chartered } \\
\text { in the } \\
\text { United States }\end{array}$ & Total & $\begin{array}{c}\text { Foreign } \\
\text { bank } \\
\text { share of } \\
\text { U.S. } \\
\text { commercial } \\
\text { bank assets } \\
\text { (percent) }\end{array}$ & $\begin{array}{c}\text { Memo: } \\
\text { Number of } \\
\text { foreign } \\
\text { banks with } \\
\text { U.S. banking } \\
\text { offices }\end{array}$ \\
\hline $1975 \ldots$ & 38 & 12 & 50 & 4.6 & 79 \\
$1980 \ldots$ & 148 & 68 & 216 & 11.8 & 153 \\
$1985 \ldots$ & 312 & 111 & 424 & 14.9 & 244 \\
$1990 \ldots$ & 628 & 148 & 776 & 23.7 & 283 \\
$1995 \ldots$ & 763 & 201 & 964 & 24.1 & 275 \\
$1996 \ldots$ & 822 & 189 & 1,011 & 24.1 & 267 \\
$1997 \ldots$ & 927 & 214 & 1,141 & 25.0 & 264 \\
1998 & 903 & 231 & 1,134 & 22.6 & 243 \\
\hline
\end{tabular}


7. Assets of U.S. branches and agencies of foreign banks, by country of parent bank, selected years, 1988-98 Billions of dollars except as noted

\begin{tabular}{|c|c|c|c|c|c|c|c|}
\hline \multirow{2}{*}{ Parent country } & \multirow{2}{*}{1988} & \multirow{2}{*}{1990} & \multirow{2}{*}{1992} & \multirow{2}{*}{1994} & \multirow{2}{*}{1996} & \multicolumn{2}{|c|}{1998} \\
\hline & & & & & & Amount & Percent \\
\hline Europe . & 139.5 & 176.5 & 269.0 & 292.5 & 392.4 & 519.4 & 57.5 \\
\hline Austria & 1.2 & 2.4 & 4.2 & 4.1 & 4.4 & 7.6 & .8 \\
\hline Belgium & 3.1 & 4.6 & 4.8 & 3.9 & 5.5 & 8.4 & .9 \\
\hline France .. & 25.1 & 32.5 & 73.3 & 90.0 & 127.6 & 132.7 & 14.7 \\
\hline Germany & 13.0 & 16.2 & 30.8 & 43.3 & 78.6 & 139.4 & 15.4 \\
\hline Italy ..... & 39.0 & 47.0 & 39.2 & 34.3 & 29.6 & 33.1 & 3.7 \\
\hline Netherlands & 8.5 & 10.7 & 20.4 & 18.4 & 30.7 & 47.5 & 5.3 \\
\hline Spain . & 3.8 & 7.6 & 7.8 & 8.6 & 10.8 & 15.2 & 1.7 \\
\hline Sweden .... & .3 & 5.3 & 11.8 & 6.9 & 7.5 & 15.0 & 1.7 \\
\hline Switzerland & 23.9 & 25.6 & 44.0 & 47.9 & 53.6 & 60.1 & 6.7 \\
\hline United Kingdom & 15.1 & 16.2 & 22.0 & 23.7 & 32.3 & 46.7 & 5.2 \\
\hline Other ............ & 6.5 & 8.4 & 10.7 & 11.3 & 12.0 & 13.7 & 1.5 \\
\hline Latin America & 11.3 & 12.2 & 11.8 & 10.7 & 12.4 & 12.6 & 1.4 \\
\hline Argentina .. & .9 & 1.0 & 1.2 & 1.5 & 2.0 & 1.2 & .1 \\
\hline Brazil ... & 3.9 & 3.9 & 3.5 & 4.2 & 4.0 & 4.0 & .4 \\
\hline Mexico & 3.7 & 4.7 & 3.6 & 2.2 & 2.9 & 3.0 & .3 \\
\hline Venezuela & 1.4 & 1.4 & 1.6 & 1.0 & 1.2 & 1.4 & .2 \\
\hline Other ...... & 1.4 & 1.4 & 1.9 & 1.8 & 2.3 & 3.0 & .3 \\
\hline Asia and Middle East & 330.6 & 402.8 & 377.8 & 385.8 & 348.8 & 252.9 & 28.0 \\
\hline China, People's Republic & 1.0 & 1.4 & 2.4 & 3.1 & 2.4 & 2.6 & .3 \\
\hline China, Taiwan .......... & 2.3 & 3.6 & 5.7 & 8.5 & 10.1 & 10.5 & 1.2 \\
\hline Hong Kong ... & 2.9 & 3.8 & 4.8 & 5.8 & 5.6 & 2.5 & .3 \\
\hline Israel ....... & 3.5 & 3.9 & 4.2 & 4.6 & 5.0 & 6.0 & .7 \\
\hline Japan . & 307.8 & 373.0 & 344.3 & 342.3 & 298.7 & 215.4 & 23.9 \\
\hline Korea & 4.1 & 6.4 & 8.5 & 12.5 & 16.6 & 6.1 & .7 \\
\hline Singapore & .4 & .9 & 1.1 & 1.8 & 2.4 & 2.5 & 3 \\
\hline Other . & 8.8 & 9.9 & 6.7 & 7.3 & 8.0 & 7.3 & .8 \\
\hline Africa & .4 & .2 & .1 & .1 & .1 & .2 & * \\
\hline Other ...... & 33.1 & 36.1 & 53.6 & 52.2 & 68.7 & 117.7 & 13.0 \\
\hline Australia & 3.8 & 6.5 & 7.2 & 5.1 & 7.8 & 9.0 & 1.0 \\
\hline Canada .. & 28.4 & 28.5 & 45.0 & 47.2 & 60.9 & 108.8 & 12.0 \\
\hline Other .. & .9 & 1.1 & 1.4 & $*$ & $*$ & $*$ & $*$ \\
\hline Total & 514.9 & 627.9 & 712.4 & 741.3 & 822.4 & 902.8 & 100.0 \\
\hline
\end{tabular}

*Less than 0.05 percent or $\$ 50$ million.

offices to open in the United States that U.S. banks have abroad, and they face similar advantages and disadvantages with each type. As with U.S. banks, foreign banks generally prefer to operate through branch offices, although subsidiaries offer some key features.

\section{U.S. Branches and Agencies}

As with U.S. banks operating abroad, foreign banks prefer to operate in the United States through branches (and agencies) because of the broad banking powers afforded such offices. Throughout the 1980s, Japanese banks heavily dominated the figures for assets of U.S. branches and agencies of foreign banks, building their share to nearly 60 percent by the end of 1990. Although they remain the largest national contingent, their assets have declined markedly, from $\$ 373$ billion at year-end 1990 to $\$ 215$ billion - and only a 24 percent share-at yearend 1998 (table 7).
As the assets of Japanese banks declined, those of French, German, and Canadian banks climbed, with each accounting for more than $\$ 100$ billion at yearend 1998. Combined, these three nationalities now account for more than 40 percent of the assets of all U.S. branch and agency offices of foreign banks. With the addition of 5 percent to 7 percent shares each of Dutch, Swiss, and British banks, the "foreign bank share" of the U.S. banking market is much more diversified among foreign nationalities today than it was a decade ago. At the end of 1998, the Herfindahl-Hirschman index for this segment of the market was 1465 , less than half the "highly concentrated" level of 3775 ten years before.

The composite balance sheet of U.S. branches and agencies has also changed notably during the past decade. In 1988, the activities of these offices were oriented more heavily toward interbank business, with more than one-half of office assets and nearly three-quarters of their funding related to affiliates and other banks; by the end of 1998, the propor- 
tions had declined to about one-third and one-half respectively.

Japanese banks are an exception to this pattern: At the end of 1998, they derived half their funding from the parent, a share typically much larger than that for the U.S. offices of banks from other developed countries. This funding pattern is due largely to the access their parents have to low-cost funding in Japan, weak loan demand in that country, and the fact that when borrowing in non-Japanese financial markets, Japanese banks must pay premium rates because of their lower credit ratings.

Foreign banks have historically considered commercial lending an important role for their U.S. offices, and they have continued to do so. U.S. branches and agencies of foreign banks held 18 percent of the U.S. commercial and industrial lending market at the beginning of the 1990s and as much as 27 percent of the market in early 1997; by the end of 1998, however, their share had declined to 23 percent. Trading activities are also important at these offices, as they are for large, internationally active banks generally. Among foreign banks, large European banks dominate the activity; for them, trading assets account for nearly 10 percent of all the assets of their U.S. branches and agencies.

At the end of 1998, nearly 80 percent of the assets of U.S. branches and agencies were booked in New York City; Chicago, at 7 percent, had the nexthighest share. Los Angeles and San Francisco together hosted 19 percent of the foreign bank offices (84 of the 454) but accounted for less than 5 percent of office assets.

\section{U.S. Subsidiaries}

Much consumer business requires a subsidiary bank, often with its own branch network and local identity. Foreign investors that seek this business have two options: to establish a new bank or to buy an existing one. During the 1970s and early 1980s, foreign banks sought acquisitions to benefit from what they perceived as low-priced U.S. bank stocks and, in the case of the larger acquisitions, to gain an immediate and significant market share. Foreign private individuals also acquired U.S. banks during that time.

Even banks pursuing wholesale business can find purchasing another bank the most efficient way to acquire necessary talent and market share, as indicated by Deutsche Bank's recent acquisition of Bankers Trust Company of New York. Other notable U.S. banks that are owned by foreign banks include Marine Midland Bank (owned by Hong Kong and
Shanghai Banking Corporation), Union Bank of California (Bank of Tokyo-Mitsubishi), Harris Trust (Bank of Montreal), and LaSalle Bank (ABN Amro, of the Netherlands).

Such acquisitions can provide investors with key elements of an international or global banking network and can create synergies with their other operations. Like any venture, they also carry risks and do not always succeed as planned. In addition to the difficulties that geographic distance can create in communicating and in coordinating actions, foreign acquisitions also introduce cultural differences and can pose further problems if acquirers do not adequately understand local banking markets and practices. The loss of key personnel, for whatever reason, can quickly undermine the business if activities are not managed and coordinated well.

Such mishaps have also occurred in the other direction. Particularly in the mid-1980s, U.S. banks acquired several British securities firms after the United Kingdom reduced regulations governing much of its financial system. Using new opportunities to enter the market, many U.S. and foreign banks paid large premiums to acquire British broker-dealers in order to expand their own securities activities and to gain footholds in debt and equity markets that were expected to enjoy rapid growth. Cultural differences (mostly between banking and securities firms) combined with the initial excessive euphoria to produce unsatisfactory results. Revenues frequently fell short of targets, or sometimes even of operating costs. After a few years, many of the new entrants sold or closed their acquired operations, and the local industry shrank to a more sustainable size.

\section{CONCLUSION}

The continuing growth of international banking and the strengthening of links between banking and securities markets have produced larger, more diversified financial institutions and further concentration of international activities among fewer U.S. banks. These trends are not unique to U.S. banking but apply to financial markets broadly. They are likely to continue as industry consolidation moves worldwide; the recently completed or proposed acquisitions by foreign banks of two large U.S. commercial banks, Bankers Trust and Republic National Bank of New York, support that point.

To central bankers and bank supervisors, consolidation in banking (whether domestic or international) brings both comfort and concern. On the one hand, consolidation should offer surviving institutions 


\section{Guidelines for International Banking: The Basel Committee on Bank Supervision}

The presence of foreign banks in local economies and their effects on national and global financial markets have long made it necessary for national authorities to communicate with their counterparts abroad. As the volume of international banking has increased in recent decades, so too has the need for bank supervisors and regulators to coordinate their efforts.

Since the mid-1970s, the Bank for International Settlements (BIS) in Basel, Switzerland, has performed an important role in facilitating the development and coordination of international bank supervisory policies, principally through its support of the Basel Committee on Bank Supervision. The committee, which includes the heads of supervision of the banking agencies of each of the G-10 countries and Switzerland, set forth fundamental principles for allocating supervisory responsibilities between home and host country authorities when it adopted the 1975 "Concordat." Since then the committee has produced the industry's current capital standard (the 1988 Basel Capital Accord) and has provided leadership in many other international bank supervisory matters.

Recent initiatives include, most notably, a 1997 amendment to the Accord addressing market risks that establishes new capital requirements for bank trading activitiesrequirements determined on the basis of "value at risk" calculations derived from banks' own internal models. Such an approach represents a new paradigm for bank regulation, one that is also being evaluated for credit risk. The committee has also produced guidance on sound risk-management practices for credit risk, for the management of derivatives activities and interest rate risk, and for other important bank operating and disclosure practices.

Although the committee is composed of officials of only major industrialized countries, its policies and standards have been adopted throughout the world. More than one hundred countries implement the 1988 Capital Accord, for example, and many of them also urge their banks to adopt other sound banking practices identified by the committee.

To foster stronger bank supervision worldwide, the committee in 1992 adopted minimum standards for consolidated supervision and in 1997 identified core principles of supervision-twenty-five elements of the supervisory process that the committee believes are necessary for an effective bank supervisory program. Bank supervisory agencies worldwide are encouraged to adhere to these principles and to evaluate their own practices periodically. The full document describing the core principles and other statements issued by the committee are available on the BIS web site: www.bis.org. greater financial strength and diversification of risks along with larger asset size and equity base. On the other hand, greater concentration of decisionmaking within the industry can lead to larger problems when they occur. Large problems, in turn, raise the specter of systemic risks.

Events of the past several years also provide evidence of the increased speed with which financial problems move around the globe and serve to validate concerns that central bankers have expressed for some time about the effects of technology and financial innovation. Although Russia's debt moratorium was a relatively small event in terms of international banking and capital market flows, it caused investors throughout the world to reassess their risks. For some countries and institutions, the consequences in reduced liquidity were immediate and widespread.

As nonbank investors play an ever-more-important role in financing economic growth, financial information about major borrowers is likely to become more available. Investor demands for greater transparency about risks would complement efforts by international bank supervisors and the International Mone- tary Fund to promote greater disclosure and should help bring about still broader, more efficient financial markets.

International banking has long provided attractive opportunities to U.S. and foreign banks and will clearly do so in the years ahead. The key to taking advantage of the opportunities, as always, is understanding the risks and potential returns. Further gains by banks and other financial institutions in measuring and managing risks will enhance this understanding.

As the links among banking and financial markets multiply and more events have sudden worldwide effects, supervisory agencies throughout the world will also need to continue - indeed, to strengthentheir efforts to coordinate the regulation and oversight of large banks and other financial institutions. Through the Bank for International Settlements, a substantial framework for conducting this work is already in place (see box). By developing their rules in ways compatible with sound market practice, supervisors can contribute most to a healthy and responsive international banking system for the new millennium. 
A.1 Number of foreign branches of Federal Reserve member banks, by location, selected years, 1965-98

\begin{tabular}{|c|c|c|c|c|c|c|c|c|}
\hline Location & 1965 & 1970 & 1975 & 1980 & 1985 & 1990 & 1995 & 1998 \\
\hline Europe & 43 & 116 & 166 & 186 & 210 & 157 & 131 & 141 \\
\hline Belgium .. & 4 & 10 & 10 & 8 & 9 & 5 & 5 & 5 \\
\hline France ...... & 4 & 12 & 19 & 15 & 12 & 11 & 9 & 8 \\
\hline Germany & 6 & 21 & 27 & 27 & 18 & 15 & 8 & 10 \\
\hline Greece . . & 1 & 9 & 17 & 16 & 21 & 22 & 26 & 32 \\
\hline Italy .... & 1 & 4 & 9 & 15 & 22 & 12 & 11 & 11 \\
\hline Luxembourg & 0 & 1 & 5 & 4 & 3 & 1 & 1 & 1 \\
\hline Netherlands . & 3 & 7 & 6 & 6 & 3 & 2 & 2 & 3 \\
\hline Spain ....... & 0 & 0 & 0 & 8 & 15 & 13 & 11 & 9 \\
\hline Switzerland & 1 & 7 & 9 & 9 & 12 & 11 & 7 & 7 \\
\hline United Kingdom & 21 & 44 & 49 & 53 & 68 & 42 & 30 & 30 \\
\hline Other ........... & 2 & 1 & 15 & 25 & 27 & 23 & 21 & 25 \\
\hline Latin America & 75 & 168 & 133 & 165 & 216 & 239 & 242 & 354 \\
\hline Argentina .. & 17 & 38 & 32 & 45 & 63 & 81 & 94 & 216 \\
\hline Brazil .... & 15 & 16 & 18 & 19 & 19 & 44 & 50 & 13 \\
\hline Chile .... & 3 & 17 & 1 & 6 & 30 & 40 & 39 & 44 \\
\hline Colombia ........ & 6 & 26 & 0 & 0 & 0 & 0 & 0 & 0 \\
\hline Panama....... & 12 & 29 & 30 & 32 & 28 & 20 & 18 & 22 \\
\hline Other ...... & 22 & 42 & 52 & 63 & 76 & 54 & 41 & 59 \\
\hline Caribbean & 13 & 116 & 162 & 193 & 193 & 155 & 124 & 108 \\
\hline Bahamas & 3 & 61 & 73 & 75 & 74 & 52 & 39 & 27 \\
\hline Cayman Islands & 0 & 0 & 47 & 79 & 91 & 80 & 70 & 67 \\
\hline Other $\ldots \ldots \ldots \ldots$ & 10 & 55 & 42 & 39 & 28 & 23 & 15 & 14 \\
\hline Asia & 50 & 79 & 112 & 161 & 202 & 189 & 184 & 220 \\
\hline Hong Kong & 6 & 13 & 23 & 43 & 73 & 57 & 43 & 52 \\
\hline India $\ldots$. & 6 & 11 & 9 & 10 & 10 & 11 & 12 & 15 \\
\hline Indonesia & 0 & 6 & 5 & 5 & 5 & 6 & 7 & 8 \\
\hline Japan ..... & 14 & 15 & 31 & 29 & 30 & 33 & 36 & 37 \\
\hline Korea ..... & 0 & 3 & 3 & 12 & 19 & 24 & 22 & 23 \\
\hline Philippines & 5 & 4 & 4 & 14 & 15 & 13 & 10 & 12 \\
\hline Singapore .... & 8 & 11 & 20 & 26 & 25 & 20 & 16 & 19 \\
\hline Other $\ldots \ldots \ldots$ & 11 & 16 & 17 & 22 & 25 & 25 & 38 & 54 \\
\hline Africa & 2 & 2 & 8 & 19 & 22 & 14 & 17 & 20 \\
\hline Middle East & 5 & 12 & 20 & 31 & 31 & 22 & 22 & 23 \\
\hline U.S. territories & 23 & 43 & 65 & 53 & 46 & 49 & 29 & 35 \\
\hline Other & 0 & 0 & 0 & 0 & 0 & 1 & 11 & 15 \\
\hline Total & 211 & 536 & 666 & 808 & 920 & 826 & 760 & 916 \\
\hline
\end{tabular}


A.2 Assets of foreign branches of Federal Reserve member banks, by location, selected years, 1965-98 Billions of dollars

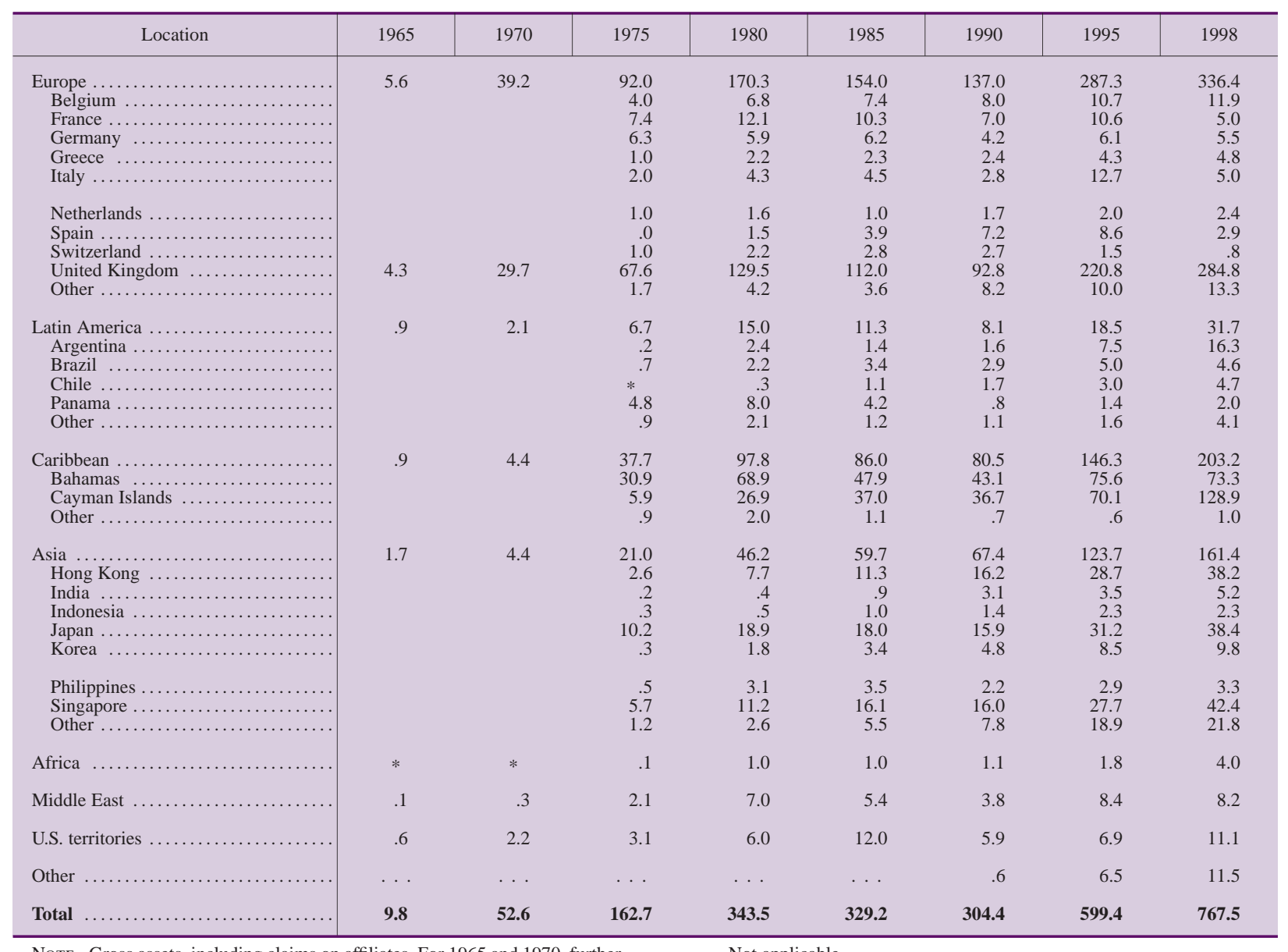

Note. Gross assets, including claims on affiliates. For 1965 and 1970, further details by country are not available. Assets are not adjusted to reflect further 